\title{
Low Cost Technology of Soy-Paneer (Tofu) Health Food from Soymilk Blended with Buffalo Milk
}

\author{
S.P. Tripathi ${ }^{1}$, S.P.S. Somvanshi ${ }^{2 *}$, Sonam Tripathi ${ }^{1}$, R.P. Patel ${ }^{1}$ and G.S. Kulmi ${ }^{1}$ \\ ${ }^{1}$ RVSKVV- Krishi Vigyan Kendra, Mandsaur-458001, Madhya Pradesh, India \\ ${ }^{2}$ BUAT- Krishi Vigyan Kendra, Hamirpur - 210301, Uttar Pradesh, India \\ *Corresponding author
}

\section{Keywords}

Soy-paneer (Tofu), Buffalo milk, Income, Farm women, Sensory parameter

Article Info

Accepted:

26 September 2018

Available Online:

10 October 2018

\section{A B S T R A C T}

Soybean (Glycine max), otherwise known as a 'miracle crop' with over 40 per cent protein and 20 per cent oil, minerals and vitamins for human food originated in China. Soy foods are nutritious, economical and provide many health benefits. A number of processed soya products are available in the market. They include Soya milk, Soya flour, Soya curd and Tofu (Soya Paneer). Besides its nutritive quality, functional properties of Soy Protein have opened avenues for producing new products and improving the quality of existing standard food products. Research trial was conducted in Mandsaur district of Madhya Pradesh (M.P.), under the Front Line Demonstration (FLD) programme, thirteen farm women were selected randomly and questionnaire was developed to study demographic parameters and extensive review of the value addition training of respondent of village. Soybean paneer (tofu) fortified by blending 70:30 ratio of soy milk and with buffalo milk then blended milk was coagulated with $2 \%$ acetic acid. After draining of whey coagulum was set as soy paneer and some was analyzed for organoleptic parameters. The result findings show that the benefit cost ratio was (1.64) found in improved method and (1.31) in traditional method, where income was increased $64.67 \%$ compare to traditional method. Farm women earn the money by value added product of fortified soy-paneer. It was found that overall acceptability increased with $30 \%$ addition of buffalo milk used for preparing soypaneer (Tofu) that increased the quality of product and also increased the income of farm women.

\section{Introduction}

Soymilk is used in various food products such as tofu, fruit flavored puddings, calcium and protein rich soymilk. A stable emulsion of oil, water, and protein, it is produced by soaking dry soybeans and grinding them with water. Soy milk contains about the same proportion of protein as cow's milk: around 3.5\%; also $2 \%$ fat, $2.9 \%$ carbohydrate, and $0.5 \%$ ash besides being rich in protein, vitamins and minerals. Soy milk is an intermediate product in the manufacture of soy paneer. Soy paneer prepared from soymilk and toned milk is a rich source of high quality proteins and vitamins, Jain \& Mittal (1992). When the milk was heated at $121^{\circ} \mathrm{C}$, inactivation of almost $90 \%$ of anti-nutritional factor as trypsin inhibitor can be achieved (Chauhan and Tomer, 1998; Chauhan et al., 1998). Soybean 
consumption directly lowers the elevated cholesterol levels, due to presence of saponin, fatty acid compounds that bind cholesterol in the blood. Soymilk is free from lactose and good choice for people who are lactose intolerant. In this study an effort has been made to prepare good quality paneer by blending tonned milk with soymilk using the technique of manufacture as recommended by Babje and Rathore (1989). Soymilk has a flat taste which is mostly not preferred in India, that's why blending of buffalo milk for of $10 \%$ to $50 \%$ can be added to improve the quality of Tofu. Vijayananda et al., (1989) reported that acid coagulated curds exhibited greater hardness, sponginess, gumminess, chewiness as compared to the salt coagulated curds. Arora and Mittal (1991) reported that addition of skim milk to soymilk increased the shear strength of the product and improved the texture. The soymilk-skim milk in 80:20 ratio was found suitable for preparation of tofu. Looking to the very strong cultural heritage of cow/ buffalo milk based dietary system in India; it is unlikely to replace milk paneer by soy Paneer. The taste, flavor and texture improved with increase in part of buffalo milk in blended milk. The overall acceptability improves with increase in part of buffalo milk in blended milk. At 30:70 per cent blend the soy paneer was not only acceptable to consumer, but it also maintained the identity as soy paneer Singh et al., (2016) and Tripathi et al., (2017). Therefore, a blend of soymilk and buffalo milk can be identified, which will suppress the beany flavor and taste of soymilk to a limit such that it is acceptable to the consumers. The purpose of the study was to determine the impact of value addition of soya-tofu for income generation as well as nutritional food security of farm family

\section{Materials and Methods}

The study was conducted in Mandsaur district of Madhya Pradesh (M.P.), Village
Gurjarbardiya was selected for conducting the Front Line Demonstration (FLD). The 13 farm women were selected randomly with good health appearance, interviewed schedule and questionnaire was developed to study demographic parameters and extensive review of the value addition training of respondent of village. Product was evaluated for organoleptic sensory parameters viz., taste, colour, texture, flavour and overall acceptability.

The samples were analyzed for organoleptic examination as per the procedure laid down by ICAR manual in Dairy Chemistry and Dairy Microbiology (1972). The production of tofu consists of preparation of soymilk and then the coagulation of soymilk to form curds which are pressed to form tofu cakes. Raw materials: Soybean was collected from the local house hold level.

\section{Soy milk preparation}

First of all clean healthy soybeans seeds were soaked in clean tap water in 1:5 ratio for $8-10$ hours until the beans split open easily and are flat on the inside. The excess water was drained and the beans were washed thoroughly to remove the outer surface. Beans were then ground in a batch of $2.0 \mathrm{~kg}$ after adding small amount of water to it and mixed well to make a pulp. The soy slurry was then brought to 10 liters by mixing hot water and boiled continuously for $25 \mathrm{~min}$ with regular stirring to prevent burning. It is important to boil the pulp as this improves both the flavor and nutritional value of the product.

After boiling, any scum and insoluble material that floats to the surface of the milk was removed. Soy slurry was the filtrated through muslin cloth and the un-dissolved residual mass known as 'okra' was removed. The obtained soy milk was further used for making fortified soy-paneer. 


\section{Preparation of fortified tofu}

Milk samples for preparation of tofu were done by blending 70:30 ratio of soy milk with buffalo milk. The combined milk was then heated with continuous stirring unless the temperature reaches $80^{\circ} \mathrm{C}$. First $20 \mathrm{ml}$ (@2 $\mathrm{ml} / \mathrm{kg}$ milk) glacial acetic acid was dissolved in $500 \mathrm{ml}$ of warm water, after then glacial acetic acid was used as a coagulant for the curdling of blend soymilk. The mixture was stirred continuously until the milk starts to coagulate. After complete curdling, milk was filtered through a clean sanitized muslin cloth into a suitable mould. To form a block of tofu, the mould is taken under paneer press and a constant pressure is given for $20 \mathrm{~min}$ to squeeze the excess water so that approximately $60 \%$ water content will reduce. Data were analyzed and simple mean percentage was calculated as formula is given below by Chandel (1991).

BC Ratio $=$ Total benefit (Goss profit) in Rs / Total cost of input (Expenditure) in Rs.

FWP $=($ Farm Women Practice $), \quad$ IP $=$ (Improved Practice), $\mathrm{BCR}=($ Benefit Cost Ratio)
Income increases (\%): Output - Input/ Input $\times$ 100

\section{Results and Discussion}

The results show that the Benefit Cost Ratio (BCR) was found in improved practice (1.64) and (1.33) in traditional practice, where income increased by $64.67 \%$ compared to traditional method (Table 1 and 2).

The data (Table 3) revealed that sensory parameters viz., colour, texture, flavor, taste and overall acceptability were found superior in improved practice as compared to the traditional practice. Similar result is also reported by Mitra et al., (2013), Singh et al., (2016) and Tripathi et al., (2017).

BC Ratio $=$ Gross profit $/$ Cost of input

$\mathrm{FWP}=1040 / 780=1.33$

$\mathrm{IP}=5780 / 3510=1.64$

Income increases $(\%)$ - (Gross profit - Cost of input/ Cost of input) $\times 100$

FP $-(1040-780) / 780 \times 100=33.33 \%$

IP - $(5780-3510) / 3510 \times 100=64.67 \%$

Table.1 Item used for soya-paneer (tofu) fortified with buffalo milk

\begin{tabular}{|l|l|c|}
\hline S. No & \multicolumn{1}{|c|}{ Particulars required } & Quantity \\
\hline $\mathbf{1 .}$ & Soybean & $26 \mathrm{~kg}$ \\
\hline $\mathbf{2 .}$ & Buffalo Milk & $39 \mathrm{liter}$ \\
\hline $\mathbf{3 .}$ & Glacial acetic acid & $250 \mathrm{ml}$ \\
\hline $\mathbf{4 .}$ & Muslin cloth & $2 \mathrm{Meter}$ \\
\hline $\mathbf{5 .}$ & Paneer press & 01 \\
\hline $\mathbf{6 .}$ & Cooking range & 01 \\
\hline $\mathbf{7 .}$ & LPG Stove & 01 \\
\hline $\mathbf{8 .}$ & Mixer grinder & 01 \\
\hline $\mathbf{9 .}$ & Packaging material & $800 \mathrm{~g}$ \\
\hline $\mathbf{1 0}$ & Cutting Knife & 01 \\
\hline $\mathbf{1 1}$ & Electronic Balance(5kg capacity) & 01 \\
\hline
\end{tabular}


Table.2 Economic parameters for soy-paneer fortified with buffalo milk

\begin{tabular}{|l|}
\hline Particular \\
\hline No. of trials \\
\hline No. of farm women involved \\
\hline Cost of (30 kg) raw material of in Rs. \\
\hline Output of Production kg/day \\
\hline Cost of produce/kg in (Rs.) \\
\hline Av. sale cost of produce \\
\hline Gross profit of produce Rs. \\
\hline Net Return in Rs. \\
\hline Income increase (\%) \\
\hline Benefit Cost Ratio (BCR) \\
\hline
\end{tabular}

Blended Soya-paneer (70:30)

\begin{tabular}{|c|}
\hline 01.00 \\
\hline 13.00 \\
\hline 3510.00 \\
\hline 34.00 \\
\hline 103.23 \\
\hline 170.00 \\
\hline 5780.00 \\
\hline 2270.00 \\
\hline 64.67 \\
\hline
\end{tabular}

Table.3 Organoleptic test of fortified Soya-paneer blended with buffalo milk

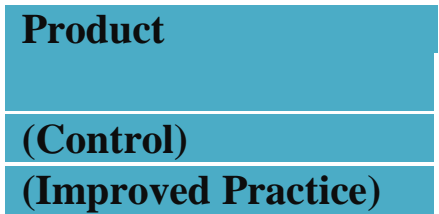

\begin{tabular}{|c|c|}
\hline Colour & Texture \\
\hline 5.0 & 5.1 \\
\hline 7.0 & 7.5 \\
\hline
\end{tabular}

\section{Sensory Attributes}

Flavour Taste

\begin{tabular}{l|l|l}
\hline 5.6 & 5.7 \\
\hline 6.5 & 7.7
\end{tabular}

\begin{tabular}{l|l}
6.5 & 7.7
\end{tabular}

Overall acceptability

5.5
7.7

It was concluded that product with $70 \%$ soy milk and $30 \%$ buffalo milk can be utilized for the production of soy paneer with higher consumer acceptability, benefit cost ratio was (1.64) found in improved practice and (1.33) in traditional practice, where income increased was $64.67 \%$ compare to traditional practice. Soya-Paneer (70:30) fortified blended with buffalo milk was superior in quality with respect to its physical and chemical parameters and increase the income of farm women and it could be a startup for small scale entrepreneur for rural area. Farm women earn the money by value added product of soybean paneer (tofu).

\section{Acknowledgment}

We also express my heartfelt thanks to the Director, ATARI, (ICAR) Zone IX, Jabalpur (M.P.) and Director Extension Services, RVS Agriculture University, Gwalior (M.P.) for providing facilities, financial support and valuable guidance for the research work.

\section{References}

Arora, S. and Mittal, B. K. (1991). Preparation and evaluation of soy paneer. J Food Sci. Technol., 28(1): 1517.

Babje, J.S. and Rathore, S.D. (1989). Effect of blending soymilk with buffalo milk in quality paneer. J. Food Sci. \& Tech. (Mysore), 29(2): 119-120

Chandel, S.R.S. (1991). A handbook of agriculture statistics, 8th Ed., Anchal Prakashan, Kanpur (U.P.) INDIA.

Chauhan, G. S. and Tomer, N. S. (1998). Varietal effect on quality of fried soy snacks. J. Food Sci. Technol., 35(2): 171-173.

Chauhan, S. K.; Tyagi, S. M. and Chauhan, G. S. (1998). Effect of various preservatives on shelf of tofu. J Food Sci Technol., 35(1): 72-73.

ICAR (1972). Manual in dairy chemistry, Indian Council of Agricultural Research, New Delhi, India. 
ICAR (1972). Manual in dairy microbiology, Indian council of agricultural research, New Delhi India.

Jain, A. and Mittal, B.K. (1992). Quality characteristics of paneer prepared from different varieties of soybeans. J. Food Sci. \& Tech., 29: 298-300.

Mitra, J.; Jha, A, Alam, T.; Singh, D. S., Ranjan, S.K. Pathak, S and Naz, A. (2013). Sensory and textural properties of tofu manufactured by blending buffalo milk Asian J. Dairy \& Food Res., 32 (2): 135-138,

Singh, Mohan Verma, D.N. and Kumar, D (2016) Techno-economic feasibility of
soy-Tofu a health food in Indian context Asian J. Dairy \& Food Res, 35(1) 23-27 Tripathi, S.P.; Somvanshi, S.P.S., Kulmi, G.S., Gaur, Shashi, Singh, Mohan and Kumar Narendra (2017) Income generation of farm women by soypaneer (tofu) blending with buffalo milk Progressive Research-An International journal, 12 (IV): 2625-2627

Vijayananda, P.; Mittal, B. K. and Kulshrestha, M. (1989). Instrumental texture profile analysis of soybean curds prepared by acid and salt coagulation. $J$ Food Sci Technol 26: 223-224.

\section{How to cite this article:}

Tripathi, S.P., S.P.S. Somvanshi, Sonam Tripathi, R.P. Patel and Kulmi, G.S. 2018. Low Cost Technology of Soy-Paneer (Tofu) Health Food from Soymilk Blended with Buffalo Milk. Int.J.Curr.Microbiol.App.Sci. 7(10): 3554-3558. doi: https://doi.org/10.20546/ijcmas.2018.710.412 